\title{
ANALISIS METODE COMMUNICATIVE LANGUAGE TEACHING TERHADAP KEMAMPUAN BERBICARA BAHASA INGGRIS GURU-GURU SMK DAN SMP ISLAM MANDIRI BOJONG GEDE BOGOR
}

\author{
Iwan Budiarso \\ Program Studi Informatika, Universitas Indraprasta PGRI \\ budiarso.iwan@gmail.com
}

\begin{abstract}
Abstrak
Dalam mempelajari bahasa Inggris, kemampuan berbicara merupakan aspek yang sangat penting, terutama bagi para pengajar. Pelaksanaan di kelas, pengajar diharapkan dapat menjadi fasilitator dan motivator yang baik supaya peserta didik mereka memiliki semangat belajar yang terus meningkat. Salah satu metode pengajaran yang dapat diterapkan adalah Communicative Language Teaching (CLT). Tujuan dari penelitian ini ialah untuk meningkatkan motivasi, kreativitas, eksplorasi pengajar terhadap kemampuan berkomunikasi bahasa Inggris pengajar. Melalui metode pengajaran ini diharapkan dapat menambah pengalaman belajar yang baru bagi para pengajar. Penelitian ini adalah penelitian tindakan kelas yang dilakukan di Yayasan Islam Terpadu Mandiri di Bojonggede Bogor. Terdapat dua sekolah yang terdiri dari SMK Mandiri dan SMP Islam Mandiri. Total pengajar kedua sekolah tersebut sebanyak 35 orang, mereka adalah yang dijadikan objek dalam penelitian ini. Metode yang digunakan dalam penelitian ini adalah metode deskriptif dengan pendekatan kualitatif. Pengumpulan data dilakukan melalui observasi dan pencatatan nilai dari masing-masing tahap penelitian. Hasil penelitian menunjukan adanya peningkatan kemampuan berkomunikasi Bahasa Inggris yang dapat dilihat dari nilai rata-ratanya. Kata Kunci : Metode Pengajaran, Communicative Language Teaching (CLT), Kemampuan Berkomunikasi Bisnis
\end{abstract}

\begin{abstract}
In learning English, speaking ability is a very important aspect, especially for teachers. Implementation in class, the teachers are expected to be good facilitators and motivators so their students have increasingly spirit in learning. One of teaching method that can be applied is Communicative Language Teaching (CLT). The purpose of this research is to build motivation, creativity, and teacher's ability of speaking business English. Using this teaching method can give new learning experiences to the teachers. This research is a classroom action research in Yayasan Islam Terpadu Mandiri Bojonggede Bogor. There are two schools, SMK Mandiri and SMP Islam Mandiri. The total number of teachers are 35 people. They are the object of this research. Methods of the research is descriptive with a qualitatif approach. Data collection is done through observation and recording of scores from each research stage. The results of the research show an increase in English business communication skills which can be seen from the average scores.
\end{abstract}

Key Words: teaching methods, Communicative Language Teaching (CLT), Ability of Speaking Business English

\section{PENDAHULUAN}

SMK dan SMP Islam Mandiri Bojonggede berlokasi di Desa Kedung Waringin Kecamatan Bojonggede Kabupaten Bogor di bawah naungan Yayasan Islam Terpadu Mandiri dengan pembagian dua jadwal belajar, kelas pagi dan kelas siang. SMK
Mandiri pada kelas pagi dan SMP Islam Mandiri pada kelas siang. Jumlah ruang kelas yang tersedia adalah sebanyak 10 kelas dengan dua lantai. Jumlah siswa yang menempuh pendidikan di sekolah ini sekitar 500 siswa dan memiliki jumlah tenaga pengajar sebanyak 20 orang guru untuk 
SMK Mandiri dan 15 orang guru untuk SMP Islam Mandiri.

Dengan terbatasnya jumlah kelas yang ada, tentu tidak dapat menciptakan suasana belajar yang kondusif dan maksimal sehingga proses kegiatan belajar mengajar di sekolah memiliki banyak hambatan, terutama dalam belajar Bahasa Inggris. Berdasarkan data yang diperoleh dari hasil observasi awal, peneliti mengamati pola pembelajaran bahasa Inggris yang diberikan oleh guru SMK Mandiri dan SMP Islam Mandiri dengan menggunakan metode pengajaran yang konvensional, seperti pola hafalan dan tidak ada interaksi yang baik sesama siswa, sehingga dalam proses pembelajarannya, siswa tidak memiliki motivasi yang tinggi untuk mengikuti setiap kegiatan pembelajaran bahasa Inggris yang diberikan dengan alokasi waktu sangat terbatas, dua kali pertemuan, masingmasing 90 menit setiap pertemuannya.

Berdasarkan sejumlah pengamatan yang dilakukan, peneliti mencoba memberikan kontribusi dalam hal pemberian input metode pengajaran. Penggunaan metode pengajaran yang sesuai dengan kebutuhan pada sebuah institusi pendidikan, sangat penting untuk menunjang keberhasilan kegiatan belajar mengajar. Tidak ada metode pengajaran yang bersifat mutlak, tetapi harus disesuaikan dengan kebutuhan peserta didik, kondisi, budaya, tempat tinggal, sarana, prasarana, dan lain sebagainya. Hal ini diungkapkan oleh [1] seperti terurai dalam bagan di bawah ini.

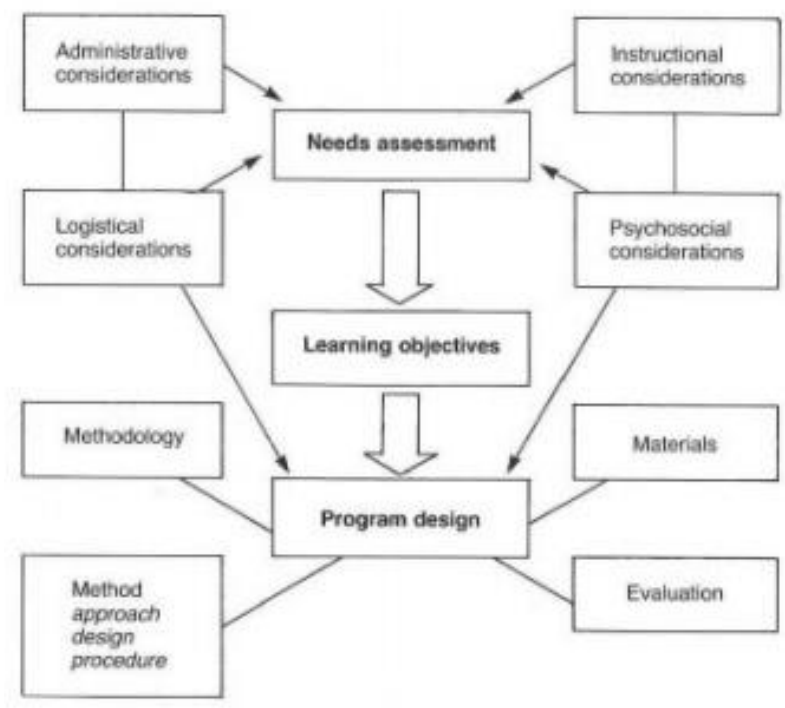

Gambar 1. Proses kegiatan belajar mengajar yang disesuaikan dengan kebutuhan peserta didik

Dari bagan di atas dapat dipahami bahwa penggunaan metode proses kegiatan belajar mengajar harus disesuaikan dengan kebutuhan peserta didik dengan cara dilakukannya need assessment/pretest untuk dapat diketahui kemampuan awal dari peserta didik, tujuan pembelajaran juga harus jelas, serta rancangan dari program pembelajaran juga harus jelas. Selain itu juga diperlukan pertimbangan administrasi, instruksi, logistic, dan psikososial untuk bersinergi antara pendekatan, metode, materi, dan evaluasi yang diperlukan. Selain itu, halhal yang perlu diperhatikan dari keberhasilan kegiatan belajar mengajar adalah guru tidak hanya menyampaikan materi, tetapi memahami apa yang dibutuhkan dan apa yang harus 
dilakukan kepada peserta didiknya. " $A$ simple answer to the question "What makes a good teacher?" therefor, is that good teacher care more about their students' learning than they do about their own teaching" [2].

Dapat diketahui bahwa pembelajaran bahasa merupakan aspek pembelajaran yang kompleks dimana proses pembelajaran keterampilan dasar berbahasa seperti keterampilan berbicara (speaking), menyimak (listening), menulis (writing) dan membaca (reading) harus terintegrasikan dengan baik satu sama lain. Pada prosesnya, seorang pengajar diharapkan dapat menjadi fasilitator yang baik agar proses pembelajaran bahasa dapat berjalan dengan lancar. "The need for teachers to motivate students through enjoyable and interesting classes; and quite a few wanted their teachers to be 'wellprepared' and to be teachers they could confidence in"[2] mengatakan bahwa, Dengan kata lain, sebagai seorang pengajar yang professional diharuskan untuk dapat menciptakan suasana belajar yang kondusif dan menyenangkan. Melalui persiapan mengajar yang matang dan pemberian materi pembelajaran yang sesuai mampu memenuhi kebutuhan belajar siswa sekaligus dapat mengatasi berbagai kendala dalam mempelajari bahasa.

Selain persiapan mengajar yang matang dan pemberian materi yang sesuai dengan kebutuhan siswa, pemilihan metode pembelajaran yang digunakan dalam proses pembelajaran bahasa di kelas juga berperan dalam meningkatkan kualitas pengajaran yang bertujuan untuk meningkatkan motivasi siswa dalam mempelajari bahasa. "The method by which students are taught must have some effects on their motivation... If the student loses confidence in the method, he or she will become de-motivated. And the student's confidence in the method is largely in the hands of the most important factor affecting intrinsic motivation, the teacher" [2].

Dalam hal ini, pemilihan metode pembelajaran yang tepat dapat dilakukan demi meningkatkan kualitas pengajaran sehingga dapat menghasilkan ouput belajar siswa yang berkualitas secara maksimal. Salah satu metode pembelajaran yang dapat diterapkan dalam pengajaran keterampilan berbicara adalah metode Communicative Language Teaching (CLT). Metode pembelajaran Communicative Language Teaching atau disebut juga dengan Communicative Approach adalah metode pembelajaran yang memberikan penekanan pembelajaran pada interaksi siswa sebagai tujuan akhir pembelajaran.

Metode pembelajaran CLT merupakan serangkaian langkah pengajaran yang menitikberatkan pada pembelajaran bahasa yang komunikatif"It refers to a diverse set of principles that reflect a communicative view of language and language learning and that can be used to support a wide variety of classroom procedures"[1]. Prinsip-prinsip dari serangkaian prosedur pelaksanaan metode CLT di dalam pengajaran di kelas harus meliputi pembelajaran bahasa secara komunikatif.

Lima karakteristik penerapan metode CLT, yaitu: 1) appropriateness, yaitu penerapan bahasa yang sesuai dengan konteks penggunaannya, baik dari segi formalitas maupun situasi percakapan; 2) message focus, yaitu pemahaman makna bahasa terhadap makna sebenarnya dimana perpindahan informasi terjadi dalam proses pembelajaran; 3) psycholonguistic processing, yaitu penggunaan 
kemampuan kognitif dan proses lainnya dalam pemerolehan bahasa; 4) risk taking, yaitu penggunaan berbagai strategi komunikasi dimana siswa dapat belajar dari kesalahan berbahasa yang pernah dilakukannya; dan 5) free practice, yaitu penggunaan berbagai kemampuan dasar berbahasa dalam pembelajaran bahasa [3].

Tahapan pembelajaran bahasa melalui penerapan metode CLT ini dianggap mampu meningkatkan kemampuan berbicara bahasa Inggris yang tentunya harus dikemas dengan berbagai kegiatan pembelajaran secara integratif agar siswa termotivasi untuk dapat berinteraksi secara maksimal. Richards membagi tahapan pembelajaran CLT ke dalam tiga bentuk kegiatan latihan, yaitu mechanical practice, meaningful practice, dan communicative practice [4]. Pada kegiatan mechanical practice, siswa diberikan kesempatan seluasluasnya untuk menggunakan bahasa tanpa harus memahami secara lebih detail fungsi penggunaan bahasa yang digunakannya. Bentuk kegiatan dalam tahap ini dapat berupa latihan pengulangan dan penggantian bentuk tata bahasa atau materi pembelajaran lainnya secara terkontrol. Selanjutnya, kegiatan meaningful practice merupakan kegiatan pembelajaran bahasa dimana siswa dapat memilih penggunaan bahasa sesuai dengan fungsinya. Pada tahapan ini, pengajar terlebih dahulu memberikan daftar kosakata yang telah disesuaikan dengan fungsi bahasa yang sesuai dengan konteks dan konsep penggunaannya. Pada tahapan terakhir, yaitu communicative practice dimana fokus pembelajaran bahasa terletak pada penggunaan bahasa di dalam konteks komunikasi secara aktual. Dari penjabaran tentang CLT di atas, maka peneliti menarapkannya pada guru-guru di Yayasan Islam Terpadu Mandiri. Pertimbangan bagi peneliti, kenapa guru lah yang menjadi objek penelitian karena dengan harapan mereka dapat menerapkan metode pengajaran CLT di dalam kelas.

Sebagai langkah awal, peneliti terlebih dahulu melatih pemahaman kosakata dan tata bahasa yang secara umum digunakan pada percakapan sederhana. Hal ini dilakukan agar para guru memahami ketepatan penggunaan kosakata dan tata bahasa tersebut terhadap konteks dan konsep yang sesuai dengan makna percakapan. Selanjutnya, para guru diberikan kesempatan seluasluasnya agar dapat melakukan interaksi dengan sesama rekannya dalam melakukan percakapan bahasa Inggris dengan tujuan untuk membangun kepercayaan diri masing-masing. Langkah-langkah tersebut tentunya akan menghasilkan score yang akan dijadikan ukuran keberhasilan dari metode yang ditawarkan. Tujuan penerapan metode pembelajaran ini para guru diharapkan dapat berlatih berkomunikasi dalam bahasa Inggris secara komprehensif dan terlibat aktif dalam interaksi komunikasi dengan sesama rekan guru, antara siswa dengan guru, maupun guru dengan pimpinan.

\section{METODE}

Metode yang digunakan dalam penelitian ini adalah metode deskriptif dengan pendekatan kualitatif. Menurut Sugiyono mendefinisikan bahwa, "Metode deskriptif adalah metode yang digunakan untuk menggambarkan atau menganalisis suatu hasil penelitian tetapi tidak digunakan untuk membuat kesimpulan yang lebih luas" [5].

Sedangkan penelitian deskriftif yang dikemukakan oleh Kuncoro, "Penelitian deskriftif meliputi kegiatan pengumpulkan data untuk menjawab pertanyaan mengenai status terakhir dari 
subyek penelitian. Tipe yang paling umum dari penelitian deskriftif meliputi penilaian terhadap individu, organisasi atau keadaan tertentu". [5].

Berdasarkan penjelasan diatas, maka metode yang digunakan dalam penelitian ini adalah metode deskriptif, yaitu hasil penelitian yang kemudian dianalisis untuk diambil kesimpulannya sehingga menghasilkan kesimpulan yang akan memperjelas gambaran mengenai objek yang diteliti.

Peneliti mengambil data penelitian ini selama tiga pertemuan dalam tiga pekan. Sebelumnya peneliti telah melakukan kunjungan ke Yayasan Islam Mandiri dan mengamati pembelajaran bahasa Inggris di dalam kelas. Tahapan yang peneliti lakukan adalah mengadopsi kerangka pemikiran dari Richards yang membagi ke dalam tiga langkah, yaitu:

\section{Mechanical Practice}

Pada tahap ini dilakukan di pertemuan pertama, peneliti memberikan materi berupa kosakata yang digunakan dalam bidang administrasi perkantoran (sight vocabulary) beserta phonetic transcription dan definisinya. Selain itu, pada tahap ini peneliti juga memberikan materi untuk pengayaan makna kalimat ke dalam bentuk kalimat sederhana terkait dengan pemahaman tata bahasa yang digunakan dalam bentuk template cards yang berisi rumusan tata bahasa beserta fungsinya. Tahapan pembelajaran ini merupakan kegiatan latihan awal bagi para guru dimana pemahaman fungsi penggunaan kosakata dan tata bahasa menjadi fokus pembelajaran. Materi pembelajaran pada tahap ini diberikan secara terkontrol sesuai dengan bidang kejuruan yang terdapat di lingkungan belajar dengan pemberian latihan yang dilakukan secara berulang. Pada kegiatan ini para guru dapat mengeksplorasi pemahaman kosakata dan tata bahasa ke dalam penulisan kalimat sederhana.

\section{Meaningful Practice}

Meaningful practice merupakan kegiatan pembelajaran yang dilakukan di pekan kedua, yakni untuk memberikan kebebasan bagi para guru dalam memilih kosakata yang akan disusun menjadi kalimat yang nantinya akan dirangkai menjadi suatu percakapan dengan menggunakan tata bahasa yang sesuai dengan konteks percakapan. Pada tahap ini, sejumlah daftar kosakata bahasa Inggris diberikan peneliti dengan berbagai bentuk kelas kata, seperti kata kerja (verb), kata benda (noun), kata sifat (adjective), dan kata keterangan (adverb) maupun fungsi kelas kata lainnya (other parts of speech) yang terkait dengan bidang administrasi perkantoran.

\section{Communicative Practice}

Pada tahap ini, di pekan yang ketiga, peneliti membagi guru ke dalam beberapa kelompok untuk melakukan percakapan bersama rekan lainnya. Berbagai tema percakapan diberikan secara aktual terhadap bidang yang sesuai dengan kejuruan di sekolah yaitu administrasi perkantoran, seperti handling documents, arranging meeting, reporting memos, emailing, dan sebagainya. Pada tahapan tiga ini para guru dapat mengaktualisasikan dirinya secara leluasa dalam melakukan improvisasi serta eksplorasi konteks percakapan dengan tetap memperhatikan kaidah kebahasaan dan fungsi kosakata yang telah dipelajari pada tahapantahapan kegiatan sebelumnya.

\section{HASIL DAN PEMBAHASAN}

Hasil dan pembahasan dari penelitian ini dapat dijabarkan bahwa pembelajaran berbicara (speaking) merupakan aspek pembelajaran yang harus terintegrasi 
dengan aspek keterampilan dasar berbahasa lainnya seperti aspek pembelajaran menulis (writing), membaca (reading), dan menyimak (listening). Pembelajaran bahasa Inggris khususnya pembelajaran berbicara kepada guru-guru memerlukan proses persiapan pengajaran yang matang, dimana peneliti harus dapat menerapkan metode dan teknik pengajaran yang sesuai dengan kebutuhan para guru tersebut mengingat latar belakang pendidikan yang dimiliki oleh setiap guru berbeda. Salah satu metode pengajaran yang dianggap mampu memberikan suasana belajar yang interaktif melalui penerapan metode communicative language teaching terhadap keterampilan berbicara bahasa Inggris para guru dengan memberikan berbagai variasi materi yang terkait dengan kebutuhan para guru secara komunikatif.

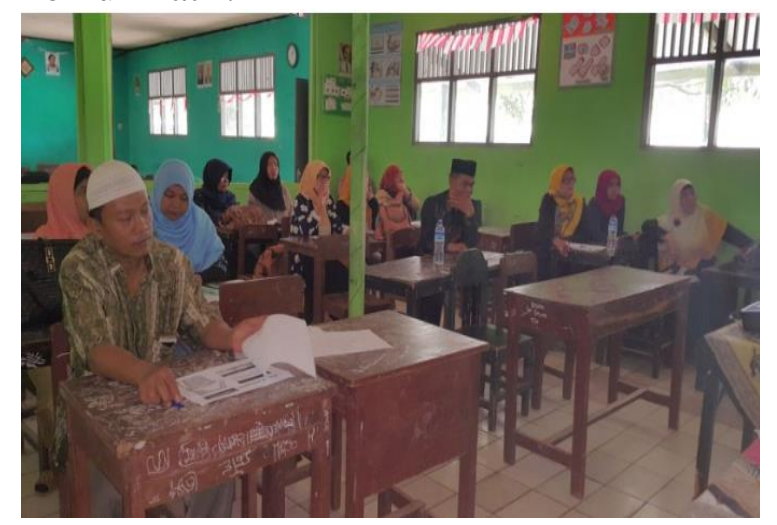

Gambar 2. Suasana belajar GuruGuru SMK Mandiri dan SMP Islam

Metode communicative language teaching dapat dikatakan sebagai metode yang efektif dalam peningkatan kemampuan berbicara bahasa Inggris para guru. Metode pengajaran ini juga mampu memberikan pemahaman yang lebih dalam terhadap kesesuian makna percakapan bahasa Inggris dengan konteks dan fungsi penggunaan percakapan sehari-hari. Selanjutnya, melalui penerapan metode pengajaran ini pula dapat memberikan nuansa baru kepada para guru untuk mempelajari bahasa Inggris. Melalui penerapan metode pengajaran ini, para guru dapat menginduksi para siswa untuk lebih meningkatkan motivasi belajar siswa di kelas maupun di luar kelas. Sebagai aplikasinya, peneliti mengamati bahwa kendala terbesar yang ditemukan adalah minimnya intensitas penggunaan bahasa Inggris di lingkungan sekolah yang di latarbelakangi oleh rendahnya rasa percaya diri untuk berkomunikasi dengan menggunakan bahasa Inggris. Kendala lainnya terletak pada latar belakang pendidikan para guru yang berbeda juga turut mempengaruhi keterbatasan guru dalam mengeksplorasi kemampuan berbicara bahasa Inggris.

Melalui penerapan metode communicative language teaching terhadap kemampuan berbicara bahasa Inggris, para guru dapat lebih mengeksplorasi kemampuan berinteraksi antara satu dengan lainnya. Dalam hal ini, para guru lebih memahami ketepatan makna percakapan yang sesuai dengan konteks dan fungsi bahasa dalam komunikasi. Pada penerapannya, metode pengajaran ini memberikan keleluasaan kepada para guru untuk dapat serta terlibat aktif secara bersama mengeksplorasi kemampuan berbicara bahasa Inggris sehingga motivasi para guru dapat meningkat secara signifikan. Hal ini dapat terlihat dari peningkatan interaksi sesama guru dalam melakukan percakapan bahasa Inggris.

Penerapan metode communicative language teaching terhadap keterampilan berbicara bahasa Inggris ini merupakan media pembelajaran untuk para guru dalam menampung aspirasi dan kreatifitas para guru dalam mengeksplorasi kemampuan berbicara bahasa Inggris dengan pemberian 
berbagai materi dan variasi kegiatan pembelajaran yang tidak didapatkan sebelumnya. Hal ini tentunya merupakan pengalaman baru bagi para guru dalam mempelajari percakapan bahasa Inggris sehingga rasa ingin tahu para guru juga semakin meningkat dikarenakan rasa antusias para guru untuk lebih memahami setiap jenis materi, latihan, serta berbagai aktivitas pembelajaran bahasa Inggris baik lisan maupun tertulis yang diberikan oleh peneliti baik dalam bentuk tugas individu maupun tugas kelompok.

Pembelajaran dengan menggunakan metode communicative language teaching dapat memberikan hasil dan manfaat yang diwujudkan ke dalam luaran (output) pembelajaran agar dapat digunakan khalayak ramai dan dapat diaplikasikan ke dalam kegiatan belajar mengajar bahasa Inggis di kelas (mechanical practice, meaningful practice, dan communicatiove practice) dengan tujuan kelas menjadi hidup dan interaksi yang baik antar siswa tecipta sehingga kemampuan berbicara siswa terus meningkat.

Penelitian terdahulu yang telah dilakukan oleh Rina menyebutkan bahwa luaran dari metode pengajaran CLT berupa Booklet yang berisi di antaranya: Relating Forms to Meaning, Communicative Activities, Some General Considerations, Functional Communication Activities, Social Interaction Activities, Listening Activities, Choosing What to Teach, A Communicative Approach and Conclusion [7].

Berikut adalah dokumentasi peneliti setelah dilaksanakannya tahap tiga (communicative practice) di dalam kelas. Peneliti telah mengumpulkan

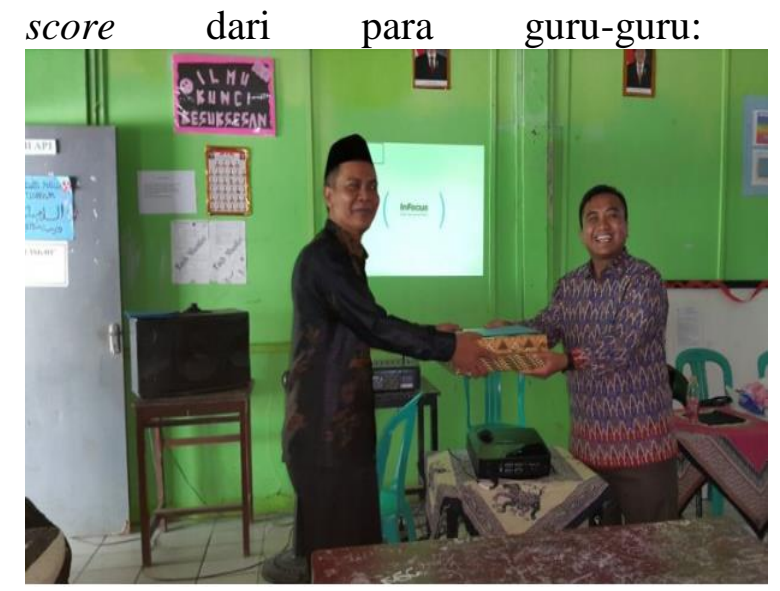

Gambar 3. Penyerahan cindera mata kepada Yayasan Islam Mandiri pada saat pertemuan terakhir

Di bawah ini adalah score guru-guru SMK Mandiri dan SMP Islam Mandiri menggunakan metode CTL:

Tabel 1: Nilai Guru Pada SMK Mandiri

\begin{tabular}{|c|c|c|c|}
\hline $\begin{array}{l}\text { Nom } \\
\text { or } \\
\text { Urut } \\
\text { Guru }\end{array}$ & $\begin{array}{c}\text { (Tahap I) } \\
\text { Mechani } \\
\text { cal } \\
\text { Practice }\end{array}$ & $\begin{array}{c}\text { (Tahap } \\
\text { II) } \\
\text { Meaning } \\
\text { ful } \\
\text { Practice }\end{array}$ & $\begin{array}{l}\text { (Tahap III) } \\
\text { Communicat } \\
\text { ive Practice }\end{array}$ \\
\hline 1 & 58 & 63 & 72 \\
\hline 2 & 59 & 62 & 71 \\
\hline 3 & 58 & 62 & 70 \\
\hline 4 & 63 & 67 & 77 \\
\hline 5 & 58 & 55 & 67 \\
\hline 6 & 53 & 60 & 67 \\
\hline 7 & 57 & 50 & 56 \\
\hline 8 & 58 & 61 & 70 \\
\hline 9 & 59 & 64 & 75 \\
\hline 10 & 59 & 63 & 76 \\
\hline 11 & 58 & 62 & 72 \\
\hline 12 & 58 & 62 & 72 \\
\hline 13 & 56 & 60 & 70 \\
\hline 14 & 58 & 65 & 77 \\
\hline 15 & 75 & 75 & 87 \\
\hline 16 & 60 & 65 & 76 \\
\hline 17 & 58 & 58 & 58 \\
\hline 18 & 70 & 75 & 86 \\
\hline 19 & 60 & 65 & 74 \\
\hline 20 & 58 & 64 & 74 \\
\hline
\end{tabular}


Tabel 2: Nilai Guru Pada SMP Mandiri

\begin{tabular}{cccc}
\hline $\begin{array}{c}\text { Nom } \\
\text { or }\end{array}$ & $\begin{array}{c}\text { (Tahap I) } \\
\text { Mechani } \\
\text { Urut }\end{array}$ & $\begin{array}{c}\text { (Tahap } \\
\text { II) } \\
\text { Meaning } \\
\text { Guru }\end{array}$ & $\begin{array}{c}\text { Practice } \\
\text { (Tahap III) } \\
\text { Communicat } \\
\text { ive Practice }\end{array}$ \\
\hline 1 & 60 & 64 & 73 \\
2 & 58 & 58 & 58 \\
3 & 70 & 75 & 85 \\
4 & 63 & 67 & 78 \\
5 & 55 & 59 & 70 \\
6 & 69 & 63 & 75 \\
7 & 68 & 62 & 72 \\
8 & 72 & 78 & 85 \\
9 & 57 & 62 & 72 \\
10 & 58 & 63 & 73 \\
11 & 63 & 67 & 77 \\
12 & 59 & 56 & 58 \\
13 & 62 & 66 & 76 \\
14 & 58 & 65 & 75 \\
15 & 63 & 69 & 77 \\
\hline
\end{tabular}

Tabel di atas dapat dilihat bahwa ada perbedaan nilai dari tiap-tiap tahap. Kolom pertama, tahap mechanical practice, adalah nilai kemampuan dasar guru-guru dalam berbicara sesuai kemampuan yang mereka miliki. Mereka diberikan kebebasan berbicara bahasa Inggris. Ada dua guru dari masingmasing sekolah menunjukan nilai yang tinggi. Dalam prakteknya, mereka menggunakan susunan kalimat yang baik, pemilihan diksi yang tepat, pengucapan yang cukup fasih, dan kelancaran dalam berbicara. Adapun selain dua guru tersebut mendapat nilai rata-rata yang sama sekitar 58-60.

Kolom tahap kedua adalah nilai hasil latihan secara terkontrol. Mereka dilatih untuk memilih kosakata yang akan disusun menjadi kalimat yang akan dirangkai menjadi suatu percakapan dengan menggunakan tata bahasa yang sesuai dengan konteks percakapan. Terdapat peningkatan nilai dalam tahap ini. Antusias belajar mereka menjadi tumbuh, hal ini terlihat dari perolehan nilai yang lebih baik dari nilai kolom pertama. Peningkatan pemerolehan nilai mereka dari tahap pertama dan kedua, sekitar 4 sampai 5 poin.

Selanjutnya, dalam kolom ketiga adalah nilai hasil improvisasi serta eksplorasi konteks percakapan para guru dengan memperhatikan kaidah kebahasaan dan fungsi kosakata yang telah dipelajari pada tahapan sebelumnya. Nilai yang dihasilkan memperlihatkan peningkatan yang sangat signifikan, meskipun ada beberapa guru dari masing-masing sekolah yang mendapatkan nilai rendah atau sama. Adapun peningkatan nilai dari tahap kedua dan ketiga sebasar 7 10 poin.

\section{SIMPULAN}

Dari hasil penelitian ini, diberikan beberapa kesimpulan tentang penerapan metode pengajaran CLT (communicative language teaching) terhadap guru-guru di Yayasan Islam Mandiri:

1. Guru-guru mampu meningkatkan kemampuan berbicara bahasa Inggris. Hal ini dapat terlihat dari kemampuan guru dalam mengaplikasikan aspek mechanical practice, meaningful practice dan communicative practice dalam melakukan percakapan bahasa Inggris secara tepat.

2. Guru-guru mampu meningkatkan kemampuan pemahaman makna percakapan bahasa Inggris sesuai dengan konteks dan fungsi penggunaan sehari-hari. Hal ini dapat dilihat dari komunikasi improvisasi antar guru yang berjalan secara interaktif dan komunikatif.

3. Metode pengajaran ini berhasil meningkatkan motivasi dan kreatifitas para guru serta 
4. memberikan nuansa pembelajaran serta pengalaman belajar bahasa Inggris yang baru, sehingga para guru dapat mengeksplorasi kemampuan berbicara bahasa Inggris secara antusias, aktif dan kreatif.

Pelaksanaan penelitian ini pada dasarnya adalah untuk meningkatkan kemampuan berbicara bahasa Inggris para guru khususnya pada peningkatan pemahaman aspek mechanical practice, meaningful practice dan communicative practice secara integratif dalam percakapan bahasa Inggris yang pada akhirnya dapat meningkatkan pemahaman konsep dan makna percakapan dalam kehidupan seharihari.

Peneliti menyarankan agar para guru khususnya di Yayasan Islam Terpadu Mandiri Bojonggede Bogor dapat terus berlatih dengan terus mengembangkan pola pembelajaran baik secara individu maupun secara kelompok. Dengan berlatih secara intensif, diharapkan dapat meningkatkan kemampuan berbicara bahasa Inggris secara lebih aktif dan dinamis.

\section{DAFTAR PUSTAKA}

[1] Richards, J.C., \& Rodgers, T.S, Approaches and Methods in Language Teaching (second Edition). Cambridge: Cambridge University Press, 2001.

[2] Hanmer, J., The Practice of English Language Learning. New York: Pearson Longman, 2010.

[3] Johnson, K., \& Johnson, H., Communicative Methodology. In K. Johnson and H. Johnson (eds.), Encylopedic Dictionary of Applied Linguistics. Oxford: Blackwell, 1998.

[4] Richards, J.C., Communicative Language Teaching Today. Cambridge: Cambridge University Press, 2006.

[5] Sugiyono, Metode Penelitian Kuantitatif dan Kualitatif. Bandung: CV. Alfabeta, 2009.

[6] Mudrajat, Kuncoro, Metode Riset untuk Bisnis dan Ekonomi. Jakarta: Erlangga, 2003.

[7] Febriyanti, H. Rina, "Penggunaan Metode Communicative Language Teaching Dalam Pengajaran Bahasa Inggris pada Guru Tutor di Bimbingan Belajar". Faktor Jurnal Ilmiah Kependidikan Vol. 4 No. 3, Hal 319-328, Nopember 2017 